63 卷 608 号 $(1997-4)$

\title{
最大の動剛性を有する静圧エアスピンドルの設計*
}

\author{
小野京右*1, 山本浩*2 \\ 崔 長 植*1, 都 築 正 浩*3
}

\section{Design of a Hydrostatic Air Bearing Spindle with Highest Possible Dynamic Stiffness}

\author{
Kyosuke ONO, Hiroshi YAMAMOTO,
} Changzhi CUI and Masahiro TSUZUKI

\begin{abstract}
In this study, we propose a new design method for maximizing the dynamic stiffness of a hydrostatic air bearing spindle. In order to decrease the rms value of dynamic displacement of the spindle against external disturbance forces, we design a hydrostatic air bearing spindle using the following procedure. First, we determine the basic dimension and supply pressure. Next, we determine the radius of radial bearing so as to minimize the static displacement at the point where the external force is imposed. Then, the non-dimensional static stiffness is determined so as to minimize the rms value of the response when the dynamic external force is applied. Finally, we determine the inside groove configuration which provides the static stiffness and the maximum damping ratio at the spindle natural frequency.
\end{abstract}

Key Words : Lubrication, Hydrostatic Bearing, Damping, Dynamic Stiffness, Air Bearing, rms Value, Optimum Design

\section{1. ま え がき}

静圧気体軸受は超精密加工技術を支える重要な非接 触位置決め機構である。そのため, 従来より剛性向上 の見地から，表面絞り軸受(1)，スロット絞り軸受 ${ }^{(2)}$, 多 孔質軸受(3) 等の軸受形式が提案されている.そして 著者らの一人も, 外周溝付き給気孔絞り形軸受構 造(4)(5) を適用した，高剛性静厌:エアスピンドル(6)を実 現している。しかし加工機用エアスピンドルのよう に, 外乱力が作用するロー夕の動的応答変位を低減す るためには、静剛性(周波数零のときの剛性)ばかりで なく，スピンドル系の共振点近傍の減衰の向上が重要 となる。

しかし，一般に静压エアスピンドルにおいては，静 剛性と, 周波数依存性を有する減衰の最大值とは相反 関係にある。そこでまず著者らは，軸受面を複数本の 細溝で分割し, 減衰が最大となる周波数を共振点に近 づけることにより, 静剛性を低下させることなく共振 点近傍の減衰比を向上し得る格子形溝軸受面構造(7)(8)

* 原税受付 1996 年: 2月26 月

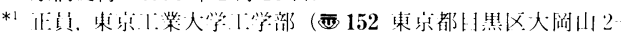
12) 1).

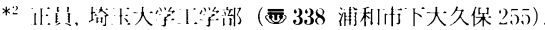

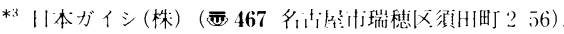

を提案した。そして, 無次元静剛性 0.4 を維持しなが ら, 共振点における減衰比を 0.1 前後に高め得ること を示した(9).

加工力などの特定の周波数特性をもつ不規則外乱力 が作用するときの, 外乱力作用点の応答変位を最小に するには，応答変位の $\mathrm{rms}$ 値が最小になるように，静 剛性と, 減衰の最大值との組合せを選択すべきであ

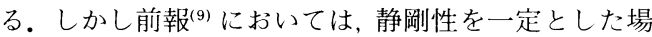
合の設計にとどまっており，外乱力に対する応答変位 を最小化しているとはいい難い.

応答変位を最小とするには, 気体膜剛性と減衰の周 波数特性を考虑して計算したスピンドルの周波数応答 関数を用いて, 応答変位の $\mathrm{rms}$ 值を求めることによ り，それが最小となる軸受寸法諸元を選択すればよ い.しかしこの場合，それぞれの軸受寸法諸元につい て, 広い周波数領域で気体膜特性を計算する必要があ

り，膨大な計算時間を要するという問題がある.

そこで本論文では，外乱力が作用する静圧エアスピ ンドルの, 応答変位の rms 值を最小にするという意味 で，最大の動剛性を有する静圧エアスピンドルの設計 手法を明らかにすることを目的とする。提案する手法 においては, 静剛性と減衰の最大值の組合せを, 簡易 計算により決定することなどにより，計算時間の短縮 
を図り，厳密計算結果と比較してその有効性を検証す る。本報で提案する設計法の既略は以下のとおりであ る.

（1）外乱力作用点の静的変位が最小となるスピン ドル軸受寸法を決定する $(2 \cdot 2$ 節).

（2）外乱力の周波数特性が与えられた場合に, 外 乱力作用点の応答変位の $\mathrm{rms}$ 值を最小にし得る, 静剛 性と減衰の最大值の組合せを決定する $(2 \cdot 3$ 節) .

（3）減衰が最大となる振動数が, 固有振動数近傍 となるように, 格子形溝軸受面の詳細設計を行う $(2 \bullet 4$ 節).

本論文では具体的な外乱力として, 共振振動数の調 和励振力と，一様な広带域スペクトル分布を有する励 振力を例にとり設計法を論じる.

\section{2. 静圧エアスピンドルの設計}

\section{$2 \cdot 1$ 基本軸受寸法諸元の決定 図 1 に設計の対} 象とする静圧エアスピンドルの概略図を示す、ロータ 断面形状が H 形の, 短軸大径の汎用エアスピンドル であり，格子形溝を有するラジアル軸受面 1 面および スラスト軸受面 2 面により構成される。基本軸受寸法 諸元の決定にあたり，まずはじめに外形寸法と給気圧 力を決定する。本設計例では市販品との比較を容易に 行うため, 外径と長さは代表的な C 社の多孔質絞り形 静压エアスピンドル AB-100 R と同寸とする。また 給気圧力を $p_{s g}=0.49 \mathrm{MPa}$ とする.

外形寸法が決まると, 一部の軸受面寸法も以下のよ うに決まる。まず軸受面はできるだけ広いほうがよい ので，スラスト軸受面外径はスラスト板外径と同寸と する．次にスラスト・ラジアル軸受面境界となる，軸 受八ウジング端部の排気のための面取りを $2 \mathrm{~mm}$ と し、ラジアル軸受長さ $2 l_{r}$ は八ウジング長さより $2 \times 2$ $=4 \mathrm{~mm}$ 短い $45 \mathrm{~mm}$ とする。図 1 に決定した基本寸

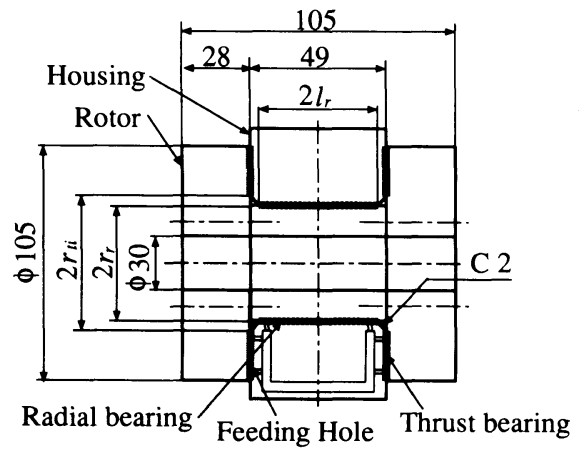

Fig. 1 Configuration of hydrostatic gas bearing spindle
法を示す。未决定の寸法はラジアル径 $r_{r}$ で, スラス 卜板内径 $r_{t i}$ は面取り寸法によって決まり $r_{t i}=r_{r}+2$ である。

次に, 軸受性能に影響をおよぼす各部の寸法を, 加 工や構造の制限条件を考虑して決定する，表 1 に以下 の制限条件を考慮して決定した, 限界的な軸受寸法諸 元を示す。まず軸受剛性および減衰の絶対量を高める には軸受すきまは狭いほうがよく，それに対忍して給 気孔径も小さくする必要がある. 軸受すきまは, 加工 組立後の軸受すきまの総合愦差を $10 \%$ 以トとするた め $5 \mu \mathrm{m}$ とした。各軸受面に 2 列 $\times 4$ 個設ける給気孔 の径は, 穴あけドリルの加に限界によって最小値が存 在し、これを $0.2 \mathrm{~mm}$ とした。次に格子形瑇について は, 減衰を高めるには溝幅は狭いほうがよいが, 放電 加工による加工可能な幅の最小值が存在する.ラジア ル軸受面のほうが溝加エしにくいため、ラジアルおよ びスラスト軸受面の溝幅を, それぞれ $0.5 \mathrm{~mm}$ 抒よび $0.3 \mathrm{~mm}$ とした。軸受端ランド幅(軸受端から給気瑇 までの距離) は, 構造上の制限から決まる。軸受効率 を高めるためには、軸受端ランド幅は小さくしたほう がよいが、給気溝内の給気孔と、給気孔に気体を尊く 給気通路も軸受端近傍に設ける必要がある。しかし, 径 3〜 $5 \mathrm{~mm}$ 程度の給気通路を軸受端に近づけ過ぎる と、軸受部の肉厚が薄くなり精度、問題となるので, 軸受端ランド幅はラジアル面 $3 \mathrm{~mm}$, スラスト面 2 $\mathrm{mm}$ とした.

$2 \cdot 2$ 静的応答変位の最小化と曲げ振動の観点から のラジアル軸受直径の決定ラジアルおよびスラス 卜軸受面の無次元剛性をそれぞれ一定とした場合、ラ ジアル軸受の直径を大きくするほど有次元のラジアル 剛性は高くなり，スラスト剛性は逆に低くなる。よっ て静的加工力を加えたときの変位を最小化するラジア ル軸受直径の最適值が存在する。

一方既報(10)に示したように, 静庄エアスピンドル はロー夕構造体としての间有振動モードを有し、この うちロータの曲げ一次拢動が支配的となる|沽有挍動数

Table 1 Fundamental design parameter values of spindle

\begin{tabular}{|l|r|}
\hline Outer diameter of thrust bearing & $105 \mathrm{~mm}$ \\
\hline Length of radial bearing & $45 \mathrm{~mm}$ \\
\hline \hline Minimum clearance & $5 \mu \mathrm{m}$ \\
\hline Minimum feeding hole diameter & $0.20 \mathrm{~mm}$ \\
\hline Minimum groove width & $0.3 \mathrm{~mm}$ (Thrust) \\
\cline { 2 - 2 } & $0.5 \mathrm{~mm}$ (Radial) \\
\hline Minimum outer land width & $2 \mathrm{~mm}$ (Thrust) \\
\cline { 2 - 2 } & $3 \mathrm{~mm}$ (Radial) \\
\hline
\end{tabular}


がもっとも低く $4 \mathrm{kHz}$ 前後である。この曲げ振動モ 一ドの減衰比は 0.02 程度と非常に低く，またこの值は 気体膜の減衰を高めてもあまり高くできないことがわ かっている.このことから, 静圧エアスピンドルの動 剛性を高めるためには, 曲げ振動モードの固有振動数 をできるだけ高める必要があるが，そのためにはラジ アル軸受径をできるだけ大きくすればよい.そこでこ の二つの観点からラジアル軸受直径を決定する.

ラジアル，スラストおよびアンギュラ方向の有次元 の剛性 $k_{r}, k_{t}$ および $k_{a}$ はそれぞれの無次元剛性 $K_{r}$, $K_{t}$ および $K_{a}$ を用いて以下のように書ける。

$$
\begin{aligned}
& k_{r}=K_{r} \frac{4 r_{r} l_{r} p_{s g}}{c}, \\
& k_{t}=K_{t} \frac{2 \pi\left(r_{t o}{ }^{2}-r_{t i}{ }^{2}\right) p_{s g}}{c}, \\
& k_{a}=K_{a} \frac{\pi\left(r_{t o}{ }^{2}-r_{t i}{ }^{2}\right)\left(r_{t o}+r_{t i}\right)^{2} p_{s g}}{4 c}
\end{aligned}
$$

ここで $2 r_{r}$ および $2 l$ はそれぞれラジアル軸受径およ び長さ、r $r_{t o}$ および $r_{t i}$ はそれぞれスラスト軸受外径お よび内径，そしてcは軸受すきまで $p_{s g}$ は給気圧力で ある。

いま加工機用エアスピンドルにおいて, 図 2 に示す ように片側のスラスト板の端部の $y$ および $z$ 方向に, それぞれ加工力 $f_{y}$ および $f_{z}$ が作用する場合を考え る. 図 2 のエアスピンドルの力学モデルにおいて, 力 と変位の関係は次式で表される。

$$
\begin{aligned}
& f_{y}=k_{r} y, \quad f_{z}=k_{t} z, \\
& f_{y} l=k_{a} \theta, \quad f_{2} r_{t o}=-k_{a} \theta
\end{aligned}
$$

傾き角 $\theta$ は微小なのでラジアルおよびスラスト方向 の変位は次式で表される。

$$
\begin{aligned}
& y=\frac{f_{y}}{k_{r}}+\frac{f_{y} l^{2}}{k_{a}} \\
& z=\frac{f_{z}}{k_{t}}+\frac{f_{2} r_{t o}{ }^{2}}{k_{a}}
\end{aligned}
$$

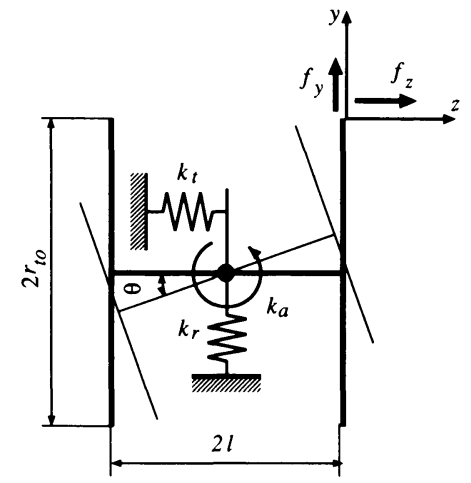

Fig. 2 spindle model for static deflection evaluation
式（1）の無次元剛性を一定とし $r_{r}$ を変化させて $k_{t}$, $k_{r}$ および $k_{a}$ を求め, 式 $(3)$ ，（4）に代入し静的変位 を求める。ここで無次元剛性は，スラストおよびラジ アル軸受面の減衰比の最大值がともにほぼ 0.1 となる ときの值である $K_{t}=0.45, K_{a}=0.45$ および $K_{r}=0.72$ を用いた(7)(8).

図 3 に,これらの条件下において, 式(3), (4)を 用いて計算した, ラジアル軸受半径 $r_{r}$ と $1 \mathrm{~N}$ の力が 作用したときの静的変位 $y$ および $z$ の関係を実線で 示す。図中に Radial, Thrust およびAngular とある 破線は, それぞれ式 (3)の第 1 項成分, 式(4)の第 1 項成分, そして式 (3)，（4)の第 2 項成分の和である. ここでは $l$ と $r_{t o}$ が等しいので, アンギュラ剛性の $y$ および $z$ 方向への寄与度は等しい。図 3 より, スラス 卜方向の変位 $z$ は $r_{r}=21 \mathrm{~mm}$ で最小となるが, ラジ アル方向の変位 $y$ は $r_{r}=32 \mathrm{~mm}$ で最小となる. スラ スト方向の変位自体がラジアル方向の変位に比べ小さ いことを考慮すれば,この場合，ラジアル方向の変位 が最小となるように $r_{r}=30 \mathrm{~mm}$ とするのがよいと考 えられる。

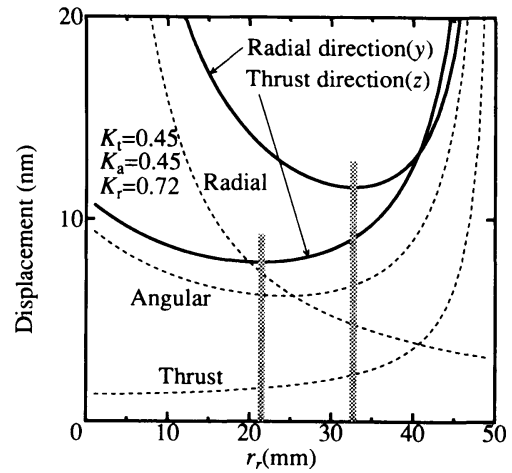

Fig. 3 Spindle edge deflection due to $1 \mathrm{~N}$ load vs. $r_{z}$

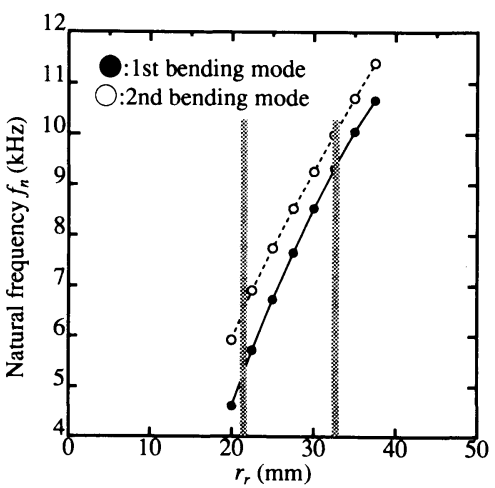

Fig. 4 Natural frequencies of bending mode vs. $r_{z}$ 
また図 4 に, ラジアル軸受半径とロータ曲げ振動モ ードの固有振動数の関係を示す. 図 4 より $r_{r} \geqq 22.5$ $\mathrm{mm}$ とすれば, 最低次の曲げ振動モードの固有振動数 は $5 \mathrm{kHz}$ より高くなることがわかる. 以上の結果か ら, スラスト方向の変位をあまり大きくせずにラジア ル方向の変位を最小にすることができ，かつ曲げ振動 の 1 次の固有振動数も $8 \mathrm{kHz}$ 以上にできるように, $2 r_{r}=60 \mathrm{~mm}$ と決定する.

\section{$2 \cdot 3$ 動的応答変位を最小とする無次元軸受剛性と}

\section{減衰比}

$2 \cdot 3 \cdot 1$ 一自由度振動系モデルによる外乱力応答変 位の rms 值研削盤などの超精密加工機のスピン ドルの精度向上のためには，加工外乱力に対する加工 点の動的応答変位を小さくすることが必要である。そ こで図 2 の力学モデルにおいて, 加工力がスラスト板 端部に作用すると仮定し, 加工力作用点の動的応答変 位の rms 值を最小にする設計法を明らかにする。

外乱力のパワースペクトルを $F(\omega)$, 外乱力が作用 する点における力に対する変位のコンプライアンス周 波数応答関数を $H(\omega)$ とすると, 外乱力が作用する点 の応答変位のパワースペクトル $X(\omega)$ は次式で表さ れる。

$$
X(\omega)=|H(\omega)|^{2} F(\omega)
$$

よって応答変位の rms 值は次式で表される。

$$
\begin{aligned}
& \sqrt{\overline{x(t)^{2}}}=\sqrt{\lim _{T \rightarrow \infty}-\frac{1}{T} \int_{0}^{T} x(t)^{2} d t} \\
& =\sqrt{\frac{1}{2 \pi} \int_{-\infty}^{\infty} X(\omega) d \omega} \\
& =\sqrt{\frac{1}{2 \pi} \int_{-\infty}^{\infty}|H(\omega)|^{2} F(\omega) d \omega}
\end{aligned}
$$

動的変位の $\mathrm{rms}$ 值を支配するのは軸受剛性と共振 周波数における減衰比である。しかし気体軸受の場 合，気体膜剛性および減衰は周波数特性を有し，減衰 は剛性と相反する性質がある。そこで，ここでは簡単 のため, 軸受・ロータ系を, 周波数に対して一定のば ねと粘性減衰で支えられたロー夕質量という一自由度 振動系にモデル化する。そしてそのロー夕質量に外乱 力が作用する場合の, 応答変位の rms 值を明らかに する。

外乱力として最も厳しいのはエアスピンドル系の共 振周波数成分であるが，研削加工力は多くの周波数成 分を有する広带域スペクトル外乱力と予想される。そ こで代表的な二つの外乱力として，軸受・ロー夕系の 共振周波数 $\omega_{n}$ を含む狭帯域スペクトル外乱力のうち 最も厳しい共振周波数の調和励振力と, パワースペク トル一定の広帯域スペクトル外乱力を検討する。
力の $\mathrm{rms}$ 值が $1 \mathrm{~N}$ の共振調和励振力 $f(t)=\sqrt{2} \sin$ $\omega_{n} t$ のパワースペクトル $F(\omega)$ は

$$
F(\omega)=\pi\left\{\delta\left(\omega-\omega_{n}\right)+\delta\left(\omega+\omega_{n}\right)\right\}
$$

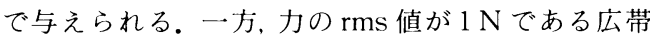
域一様スペクトル外乱力について考えると，その帯域 を増やすにつれパワースベクトルの大きさが低下す る.そこで代表例として, $5 \mathrm{kHz}$ まで一様でそれ以上 で零である場合を考えれば, rms 值が $1 \mathrm{~N}$ の広帯域外 乱力のパワースペクトル $F(\omega)$ は

$$
F(\omega)=\frac{1}{10000 \pi}
$$

で与えられる。

ロータ・軸受系の応答を支配する，主要なモードの 静剛性を $k$, 不減衰固有角振動数を $\omega_{n}$, 減衰比を $\zeta$ と すれば,ロータのコンプライアンス周波数忍答関数 $H(\omega)$ は次式となる.

$$
H(\omega)=\frac{1}{k} \cdot \frac{\omega_{n}^{2}}{-\omega^{2}+2 j \zeta \omega_{n} \omega+\omega_{n}^{2}}
$$

この主要なモードに関する, 外乱力によるロー夕の忍 答変位の $\mathrm{rms}$ 值は，共振調和励振力丁 場合，式 $(7)$, (9)を式 (6)へ代入して

$$
\sqrt{x(t)^{2}}=\frac{1}{2 k \zeta}
$$

となる。一方式 ( 8 )の広帯域一様スペクトル外乱力の 場合について考えると,ラジアル，スラストおよびア ンギュラ振動モードの固有振動数は $5 \mathrm{kHz}$ の $1 / 2$ 倍 以下であるので、式( 9 ) は $\omega>10000 \pi$ の領域では著 しく小さくなる。よって式（6)において $\omega>10000 \pi$ の領域の積分成分は無視することができ，式(8)， (9) を式（6)に代入して

$$
\sqrt{x(t)^{2}}=\sqrt{\frac{\omega_{n}}{4 k^{2} \zeta} \cdot \frac{1}{10000 \pi}} \cdot
$$

となる。式(10)，(11)から，いずれの場合も応答変位

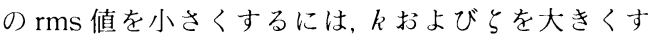
ることが重要であることがわかる。しかし広帯域スぺ クトル励振力の場合は，との効果は平方根でしかきか ないため, $k$ の影響が大きくなる。

$\mathbf{2} \cdot \mathbf{3} \cdot 2$ 円周溝付き軸受による動的忍答変位最小と なる無次元静剛性の决定静压気体軸受では, 気体 膜の剛性と減衰が周波数特性をもち, 静剛性と減衰は 相反関係にある。したがって, 格子形溝軸受面構造に 基づいて, 動的応答变位最小となる軸受を綮密に設計 するには, 残された給気孔径, 溝本数および溝深さの 諸元の値を変化させて, 式 (6)が最小となるように寸 法決定する必要がある。しかしこ0場合，変化させな ければならないパラメータが三つあり，周波数特性計 算も必要な0で、最適値の概略值がわかっていなけれ 
ば計算量が膨大となる。

そこで既報(7)(8) で示したように，減衰の極大值を軸 受共振点に同調させたときの, 最適な格子形溝軸受の 静剛性と最大減衰值は, 格子形溝がなく外周給気溝の み有する円周溝付き軸受の, 静剛性と最大減衰值とほ とんど同じであることに注目する。そして簡略設計法 として, まず表 1 に示す軸受諸元をもつ円周溝付きラ ジアルおよびスラスト軸受構造に対して, 給気孔径と 円周溝深さだけを変えて式(10)または(11)の rms 值 を最小とする静風性と減衰比の組合せを求める。ここ で減衰は，低周波数領域で負とならない範囲で円周溝 深さを大きくして極大值を最大化し、この減衰の最大 值と静剛性，ロー夕質量を用いて減衰比を計算する。

図 5 および 6 に, rms 值が $1 \mathrm{~N}$ の共振調和励振力が 図 2 のモデルに作用したときの，それぞれラジアルお よびスラスト方向の応答変位 $y$ および $z$ の rms 值と 無次元静剛性の関係を示す。ただしラジアルおよびス ラスト方向の応答変位にはアンギュラモードも影響す るが, ここでは基本的な設計手法を示すため，それぞ れラジアル抢よびスラスト振動モードのみの一自由度 振動系とみなしている。また図 $7 ， 8$ に, 式(8)の一 様な広帯域スペクトルを有する外乱力が図 2 のモデル に作用したときの，応答変位の rms 值と無次元剛性 との関係を示す.

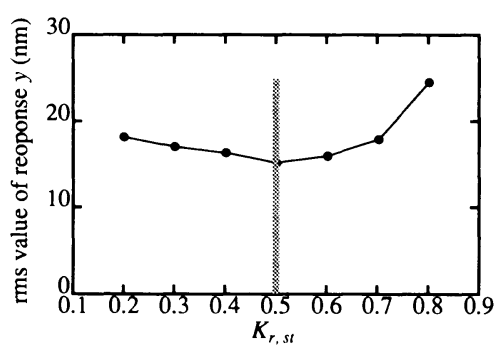

Fig. 5 rms value of $y$ vs. radial static stiffness (Resonance frequency harmonic disturbance)

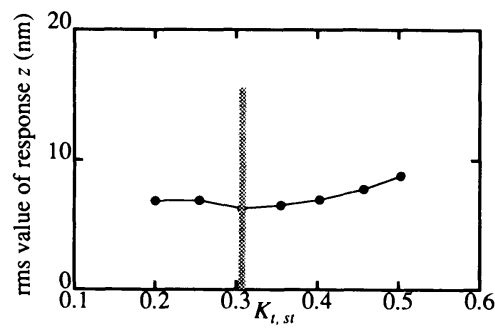

Fig. 6 rms value of $z$ vs. thrust static stiffness (Resonance ferquency harmonic disturbance)

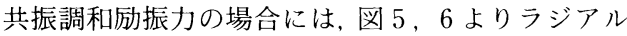
方向では無次元剛性が 0.5 のとき，またスラスト方向 では無次元剛性が 0.3 のとき, rms 值が最小になるこ とがわかる。一方，一様スペクトル外乱力の場合には， 図 7,8 よりラジアル方向静剛性は 0.6 のとき，スラ スト方向静剛性は 0.4 のとき, 応答変位の $\mathrm{rms}$ 值が 最小になる。一様スペクトル外乱力の場合のほうが最 適静剛性が大きいのは, 共振点の減衰比がやや小さく てよく，しかも共振点以下の周波数成分の応答をも剛 性により抑圧する必要があるからである。

これら両極端のスペクトル特性をもつ励振力に対す る結果から，任意のスペクトル分布をもつ外力に対す る応答変位の rms 值を最小にするには, ラジアル静 剛性を $0.5 〜 0.6$, スラスト静剛性を $0.3 \sim 0.4$ とすれ ばよいといえる. 円周溝付き軸受では，このときラジ アルおよびスラスト方向の減衣比はそれぞれ $0.19 \sim 0.24$ および $0.16 〜 0.24$ となっている.

$2 \cdot 4$ 軸受面形状の決定 研削盤用エアスピンド ルにおける加工力は一様スペクトル特性をもつと考え られる。そこで $2 \cdot 3$ 節で議論した最適な無次元静剛性 の簡易設計法において，ラジアル方向静剛性 0.6 , ス ラスト方向静剛性 0.4 を設計值として, 格子形溝を有 する軸受面の詳細設計を行う。すなわち既報(9)に示 したように，まず設計值の静剛性を満たす給気孔径を

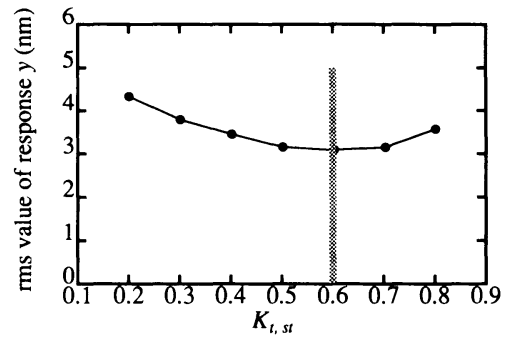

Fig. 7 rms value of $y$ vs. radial static stiffness (Wide frequency bandwidth random disturbance)

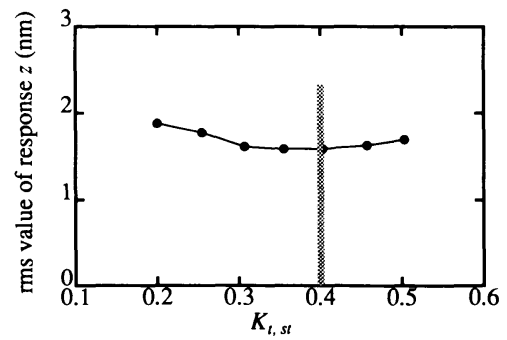

Fig. 8 rms value of $z$ vs. thrust static stiffness (Wide frequency bandwidth random disturbance) 


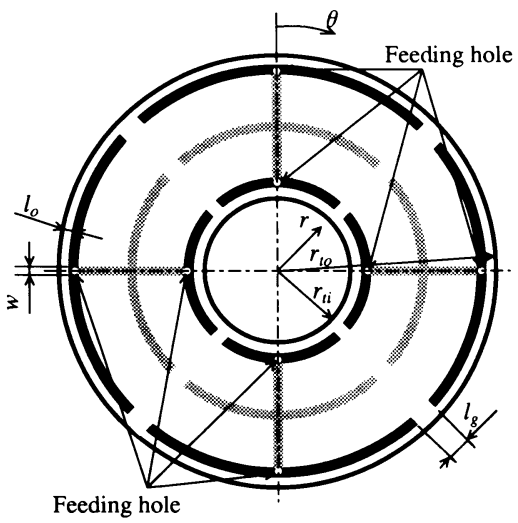

Fig. 9 Grid $^{-}$shaped groove thrust bearing $\left(N_{g \theta}=1, \quad N_{g r}=3\right)$

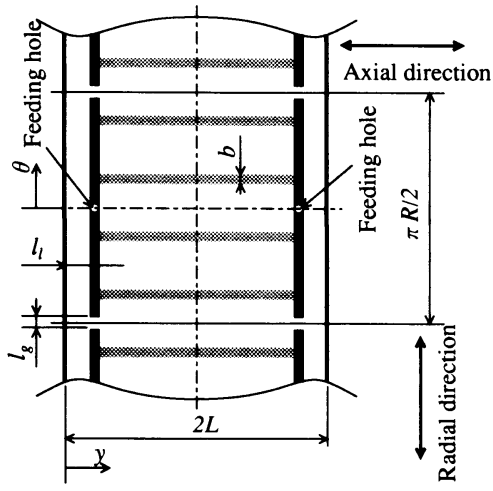

Fig. 10 Grid-shaped groove radial bearing $\left(N_{g \theta}=4, \quad N_{g y}=0\right)$

決定する。次に静剛性と压縮性剛性（周波数が非常に 高いときの剛性)の平均值で近似できる, 固有振動数 近傍における剛性と質量から固有振動数を計算する. そして求めた固有振動数において減衰比が最大となる ように，格子形溝軸受面の溝本数㧍よび深さを決定す る。ここでのスラスト軸受面には, 図 9 に示すような 複数の円周方向溝を有する Type 1 を用いた。またう ジアル軸受面には, 図 10 に示すような複数の軸方向 满を有するType 2 を用いた。表 3 および 2 に，それ ぞれ決定したスラストおよびラジアル軸受面の軸受設 計諸元を示す。

表 4 に, 表 2 および 3 に示した寸法諸元を用いて計 算したエアスピンドルの性能諸元を示す。スラスト軸 受はスラスト力向無次元静剛性 0.4 を満たす。そして 低周波数領域で㼩衰が負とならずに，スラスト振動モ 一ド抒よびアンギュラ振動モードの減衰比はそれぞれ 0.112 および 0.161 となる。またラジアル軸受はラジ
Table 2 Detailed specification of hydrostatic gas radial bearing

\begin{tabular}{|lcc|c|}
\hline \multicolumn{3}{|c|}{ Design parameter } & Design value \\
\hline Number of feeding holes & & & $4 \times 2=8$ \\
Diameter & $2 r_{r}$ & $(\mathrm{~mm})$ & 60.0 \\
Length & $2 l_{r}$ & $(\mathrm{~mm})$ & 45.0 \\
Clearance & $c$ & $(\mu \mathrm{m})$ & $5_{-0.5}^{0}$ \\
Feeding hole diameter & $d_{r}$ & $(\mathrm{~mm})$ & $0.20 \pm 0.01$ \\
Groove width & $w$ & $(\mathrm{~mm})$ & 0.5 \\
Groove gap width & $l_{g}$ & $(\mathrm{~mm})$ & 2.5 \\
Land width & $l_{o}$ & $(\mathrm{~mm})$ & 3 \\
Number of dividing grooves & & \\
Axial direction & & $4 N_{g \theta}$ & $4 \times 4$ \\
Circumferencial direction & & $N_{g y}$ & 0 \\
Groove depth & $g$ & $(\mu \mathrm{m})$ & $100_{-10}^{0}$ \\
\hline
\end{tabular}

Table 3 Detailed specification of hydrostatic gas thrust bearing

\begin{tabular}{|lcc|c|}
\hline \multicolumn{2}{|c|}{ Design parameter } & Design value \\
\hline Number of feeding holes & & & $4 \times 2=8$ \\
Inner diameter & $2 r_{i}$ & $(\mathrm{~mm})$ & 64.0 \\
Outer diameter & $2 r_{o}$ & $(\mathrm{~mm})$ & 105.0 \\
Clearance & $c$ & $(\mu \mathrm{m})$ & $5.0_{-0.5}^{0}$ \\
Feeding hole diameter & $d_{t i}$ & $(\mathrm{~mm})$ & $0.28_{-0.02}^{0}$ \\
& $d_{t o}$ & $(\mathrm{~mm})$ & $0.36_{-0.03}^{0}$ \\
Groove width & $w$ & $(\mathrm{~mm})$ & 0.3 \\
Groove gap & $l_{g}$ & $(\mathrm{~mm})$ & $5 \sim 8$ \\
Land width & $l_{o}$ & $(\mathrm{~mm})$ & 2 \\
Number of dividing grooves & & \\
Radial direction & $4 N_{g \theta}$ & $1 \times 4$ \\
Circumferencial direction & $N_{g r}$ & 1 \\
Groove depth & $g$ & $(\mu \mathrm{m})$ & $150_{-10}^{0}$ \\
\hline
\end{tabular}

Table 4 Performance of designed gas bearing spindle $\left(p_{s g}=0.49 \mathrm{MPa}\right)$

\begin{tabular}{|l|l|r|r|}
\hline \multicolumn{2}{|c|}{} & $\begin{array}{r}\text { Designed } \\
\text { spindle }\end{array}$ & AB-100R \\
\hline \multirow{2}{*}{ Stiffness } & Radial $(\mathrm{N} / \mu \mathrm{m})$ & 169 & 50 \\
\cline { 2 - 4 } & Thrust $(\mathrm{N} / \mu \mathrm{m})$ & 442 & 400 \\
\hline \multirow{2}{*}{$\begin{array}{l}\text { Natural } \\
\text { Frequency } \\
(\mathrm{Hz})\end{array}$} & Radial & $1198^{* 1}$ & $1010^{* 2}$ \\
\cline { 2 - 4 } & Angular & $1224^{* 1}$ & $1480^{* 2}$ \\
\cline { 2 - 4 } & Thrust & $1937^{* 1}$ & $2000^{* 2}$ \\
\cline { 2 - 4 } & 1 st bending & $6946^{* 1}$ & $4840^{* 2}$ \\
\hline \multirow{3}{*}{$\begin{array}{l}\text { Damping } \\
\text { Ratio }\end{array}$} & Radial & $0.136^{* 1}$ & $0.120^{* 2}$ \\
\cline { 2 - 4 } & Angular & $0.161^{* 1}$ & $0.095^{* 2}$ \\
\cline { 2 - 4 } & Thrust & $0.112^{* 1}$ & $0.088^{* 2}$ \\
\cline { 2 - 4 } & 1st bending & $0.003^{* 1}$ & $0.091^{* 2}$ \\
\hline
\end{tabular}

$* 1$ Housing is supported rigidly. $p_{s g}=0.49 \mathrm{MPa}$

$* 2$ Housing is supported freely. $p_{s g}=0.40 \mathrm{MPa}$

アル無次元静剛性 0.6 を満たし, 低周波数領域で減衰 が負とならずに減衰比 0.136 となる。

比較する代表例としてとりあげた沛販の同一外形讨 法のエアスピンドルの実測值 ${ }^{(11)} も$ 比較的に示す。本 設計の場合は給気压力が 1.2 倍䯩いが, 固有振動数は 
軸受ハウジングが固定されている場合の値であり，自 由支持の場合はラジアル, スラスト方向で 1.37 倍, ア ンギュラ方向で 1.72 倍に高くなる.このことを考慮 すると, ラジアル方向の静剛性が 2 倍以上高く, また ラジアル, スラストおよびアンギュラ剛体振動モード については固有振動数と減衰比が高くなっていること がわかる.そして曲げの 1 次の振動モードに関して は, 減衰比は低くなっているものの固有振動数はかな り高くなっており, 本論文で提案した設計手法により, かなり高い動剛性を有する静压エアスピンドルを実現 できる可能性が示された。

\section{3. 設計手法の妥当性の検討}

$2 \cdot 3$ 節では設計計算量を低減するため, 応答変位の $\mathrm{rms}$ 值の計算の際には軸受剛性および減衰比は全周 波数領域で一定であると仮定している.そして格子溝 のない場合について計算した, 減衰比の最大値と静剛 性との組合せを用いて応答変位の rms 值を計算し, それを最小とする静剛性を設計基準值とした。しかし 気体膜剛性および減衰は周波数依存性があるため, 厳 密にはおのおのの静剛性の場合について, $2 \cdot 4$ 節と同 様に軸受面の詳紼設計を行った上で, そのスピンドル の周波数応答関数を用いて式 (6)の積分計算を行う必 要がある。そして, 応答変位の $\mathrm{rms}$ 值を最小とする

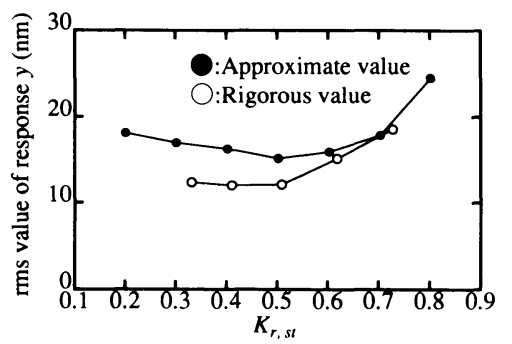

Fig. 11 Comparison of rms values of $y$ by approximate and rigorous design methods

(Resonance frequency harmonic disturbance)

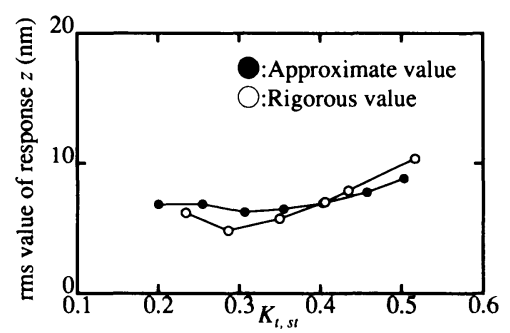

Fig. 12 Comparison of rms values of $z$ by approximate and rigorous design methods

(Resonance frequency harmonic disturbance)
軸受面形状寸法を決定する必要がある.

そこで以下では, 気体膜の周波数特性を考慮して計 算した応答変位の $\mathrm{rms}$ 值の厳密計算結果と, $2 \cdot 3$ 節で 求めた rms 值の近似計算結果を比較する。厳密計算 結果においては，それぞれの静剛性の場合について， 格子形溝本数および溝深さを変化させて, 気体膜の周 波数特性を考慮した上で式（6）の積分計算より $\mathrm{rms}$ 值を計算し, 最も $\mathrm{rms}$ 值が小さくなる場合を選択し た結果を示している。

図 11,12 に，共振調和励振力が作用した場合のラジ アルおよびスラスト方向の応答変位の $\mathrm{rms}$ 值の厳密 計算結果をそれぞれ○印で示す。また図 13,14 に，一 様な広带域スペクトルを有する外乱力が作用した場合 の, ラジアルおよびスラスト方向の応答変位の rms 值の厳密計算結果をそれぞれ○印で示す。いずれの場 合もの印で示す点は $2 \cdot 3$ 節で近似的に求めた結果であ る、いずれの場合も厳密計算結果において応答変位が 最小となる静剛性は, 近似計算結果に比べやや低くな っているが, この理由は以下のように考えられる.

$2 \cdot 3$ 節の近似計算においては, 剛性の值として静剛 性を用いているが, 減衰比を高めるためには静剛性を 小さくする必要がある。一方共振調和励振力に対する 厳密計算においては，共振振動数における気体膜剛性 を用いている。この值は静剛性と压縮性剛性のほほ平

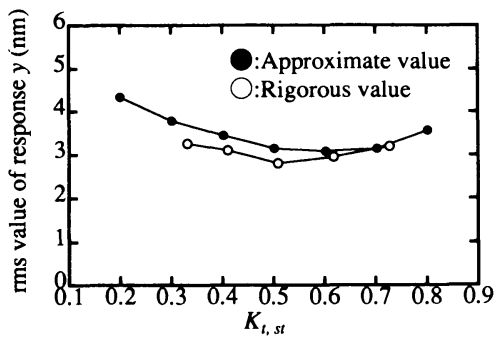

Fig. 13 Comparison of rms values of $y$ by approximate and rigorous design methods

(Wide frequency bandwidth random disturbance)

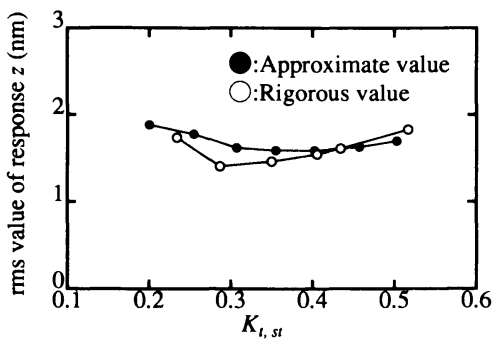

Fig. 14 Comparison of rms values of $z$ by approximate and rigorous design methods

(Wide frequency bandwidth random disturbance) 
均值となり，一般に静剛性より大きな值となる。そし て減衰比を高めるため静剛性を小さくしたときでも压 縮性剛性はあまり変わらないため, 共振振動数におけ る剛性はあまり小さくはならない.よって厳密計算に おいては, 近似計算に比べ静剛性がやや低く減衰比が 高くなるときに応答変位の rms 值は最小となる。ま た広帯域一様スペクトル分布を有する外乱力に対する 応答変位に関しても, 共振振動数近傍の振幅の影響が 大きいため同様の傾向となる。

近似計算においては剛性の值として静剛性を近似的 に用いているが，厳密計算においてはそれぞれの周波 数における気体膜剛性を用いている。そして一般に， 周波数が高くなるにつれて気体膜剛性は大きくなる が，この值は静剛性に比べ大きくなる，そこで，図 11〜14 に示すように, 応答変位の $\mathrm{rms}$ 值の厳密計算 結果は，近似計算に比べ小さくなる傾向がある。一方 溝本数が多くなるにつれ溝をあまり深くできなくな り，減衰の最大值そのものがやや低くなってしまう。 この傾向は静剛性が高い場合ほど顕著であり,このた め静剛性の高い領域で厳密計算結果の rms 值が近似 計算結果より大きくなる傾向がある.

このように近似計算結果は厳密計算結果からややず れているが, 応答変位が最小となる静剛性の值および 応答変位の $\mathrm{rms}$ 值は, 厳密数值解析結果のよい近似 值となっている．また近似計算においては，簡易計算 により決定した静剛性の場合についてのみ, 軸受面の 詳細設計を行えばよく, また, 気体膜の周波数特性を 考慮した計算を行う必要もない，そこで，rms 值が最 小となる軸受寸法諸元を選択する厳密な設計法に比 べ，(選択した静剛性の数) ×(周波数特性を計算する 際の周波数の数)相当分の, 大幅な計算時間を短縮で きるという利点がある。

図 13,14 に打ける, 応答変位の $\mathrm{rms}$ 値の最小値の 結果から, 加工外乱力に対する動的応答変位の $\mathrm{rms}$ 值を最小化する本設計法により, rms 值が $1 \mathrm{~N}$ の一様 スペクトル外乱力に対する応答変位の $\mathrm{rms}$ 值がラジ アル方向 $4 \mathrm{~nm}$ 以下, スラスト方向 $2 \mathrm{~nm}$ 以下となる 高い動剛性を有する静圧エアスピンドルが実現できる 見通しが得られた。

\section{4. ま と め}

本論文では, 超精密加工機械用静圧エアスピンドル の加工外乱力作用点の応答変位を最小にする設計論を 提案し，それに基づき，最大の動剛性を有する格子形
溝付き静圧エアスピンドルの設計例を示した。本論文 で提案した設計手法をまとめると以下のようになる.

（1）基本外径寸法および給気圧力を決定し，加工 上および構造上の制限によって決まる軸受寸法諸元の 限界值を決定する。

（2）無次元剛性一定の条件のもとで, 外乱力作用 点の静的変位が最小となり, かつ曲げ振動モードの固 有振動数が十分高くなるようにラジアル軸受径を決定 する.

（3）格子形溝のない円周溝軸受面を前提として, 給気孔径と溝深さを変化させて気体膜の静剛性と減衰 の最大值を計算する。そして，与えられた外乱力のパ ワースペクトル $F(\omega)$ とスピンドルの各振動モードに 対する周波数応答関数 $H(\omega)$ により, 剛性および減衰 が周波数によらず一定であると仮定した場合の忍答変 位の rms 值

$$
\sqrt{x(t)^{2}}=\sqrt{\frac{1}{2 \pi} \int_{-\infty}^{\infty}|H(\omega)|^{2} F(\omega) d \omega}
$$

が最小となる静剛性と減衰比を决定する。

（4）軸受系の固有振動数を気体膜静剛性および圧: 縮性剛性の平均値から推定する。そして推定した固有 振動数近傍で, 減衰比が最大となるように格子形溝本 数を決め, かつ周波数の低い領域で減衰が負にならな い範囲で溝深さが最大となるように決定する。

動剛性を最大にする本設計法により, 外径 $105 \mathrm{~mm}$, 長さ $105 \mathrm{~mm}$ の静圧エアスピンドルで, $1 \mathrm{~N}$ の $\mathrm{rms}$ 值 をもつ一様スペクトル分布外乱力による答変位の $\mathrm{rms}$ 值を, ラジアル方向 $4 \mathrm{~nm}$, スラスト方向 $2 \mathrm{~nm}$ 以 下にできる見通しが得られた。

\section{文献}

(1) Arneson, H. E. (j., U.S. Patent, 3305282(1967)

(2) Dee, C. W. and Shires, (r. L.. Trans. ASME, Ser. F, 93 4 (1971), 441-450

（3）十合显一・岡野 真・秋山好胤, 潤消，17 6(1971)，360 368.

（4）小野尔有。機論, $47424, C$ (1981)，1635-164）。

（5）小野京有・茶谷雅彦, 機論, 51-468, C (1985), 2009 2016.

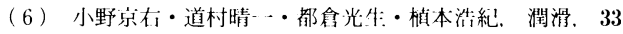
$12(1988), 915921$

(7) 山本 浩・小野宗存, 機論, 61 581, C(1995), 204211.

（8）山本 浩・小野宗有，機論，61 581，C(1995), 212219.

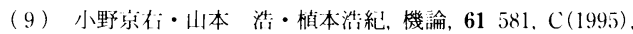
$220-227$.

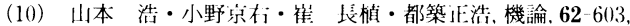
C (1996), 42944301

（11）山本碩徳・小山内英闰, 設計・製汹, $259(1990)$, 342 346 